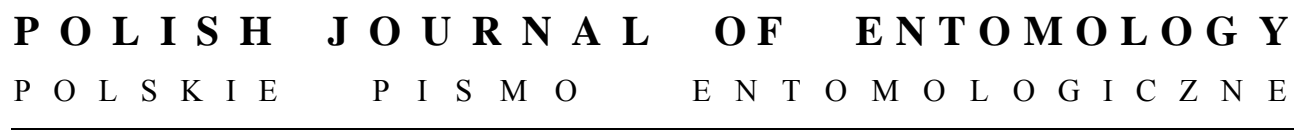

VOL. 80: 679-688

Gdynia

31 December 2011

DOI: $10.2478 / \mathrm{v} 10200-011-0052-\mathrm{x}$

\title{
Yuripopoverus africanus gen. et sp. n. from East African copal (Hemiptera: Fulgoromorpha: Ricaniidae)
}

\author{
ADAM STROIŃSKI, JACEK SZWEDO \\ Department of Palaeozoology, Museum and Institute of Zoology, \\ Polish Academy of Sciences, Wilcza 64, 00-679 Warszawa, Poland, \\ e-mail: adam@miiz.waw.pl; szwedo@miiz.waw.pl
}

\begin{abstract}
A new genus and species of the planthopper family Ricaniidae Yuripopoverus africanus gen. et sp. n. is described and illustrated on the basis of an inclusion in East African copal.
\end{abstract}

KEY WORDS: Yuripopoverus gen. n., Yuripopoverus africanus sp. n., Ricaniidae, East African resin, animè, copal, taxonomy, new genus, new species.

\section{INTRODUCTION}

The first records of planthoppers from East African resin were given by STROIŃSKI \& SzWEDO (2002), who reported inclusions from the planthopper families Derbidae (with Zoraida angolensis SYNAVE, 1973), Issidae (an unidentified adult and nymph) and Ricaniidae (with the recent genera Acroprivesa SCHMIDT, 1912 - new species A. msandarusi Stroiński et Szwedo, 2002, Osaka Distant, 1909, Pochazoides Signoret, 1860 and Pocharica SignORET, 1860). Later, STROIŃSKI (2007) described another new species - Pochazoides szwedoi. Revision of the genus Acropriesa (STROIŃSKI 2010) confirmed the status of $A$. msandarusi as a distinct species, not found among the representatives of recent fauna.

\section{Acknowledgements}

This paper is a contribution to the research grant "Extinct and extant genera in the palaeontological record of recent families of insects" from the Ministry of Science and Higher Education of Poland NN 303297937 awarded to JS for 2009-2012. 


\section{SYSTEMATICS}

Order: Hemiptera LINNAEUS, 1758

Infraorder: Fulgoromorpha EvANS, 1946

Family Ricaniidae AMYOT et SERVILLE, 1841

\section{Genus Yuripopoverus gen. n.}

\section{Type species}

Yuripopoverus africanus sp. $\mathrm{n}$.

\section{Etymology}

The genus is named after the eminent hemipterologist Professor Yuri A. Popov. Gender: masculine.

\section{Diagnosis}

Differs from Osaka DISTANT, 1909 in the following characters: tegmen with stems $\mathrm{Sc}+\mathrm{RA}, \mathrm{RP}, \mathrm{M}$ and $\mathrm{CuA}$, leaving basal cell separately (three stems $-\mathrm{Sc}+\mathrm{R}, \mathrm{M}$ and $\mathrm{CuA}$ in Osaka); nodal line absent, apical line present; hind tibia with single lateral spine (two lateral spines in Osaka); hind basitarsus as high (in lateral view) as wide, with big lateral teeth, internal teeth separated by diastemata and placed in lower plane in lateral view (hind basitarsomere longer than high, apical row of teeth of similar size arranged in line in Osaka); apical hind tarsomere longer than preceding ones (in Osaka apical tarsomere slightly longer than subapical one, basitarsomere about as long as cumulative length of subapical and apical tarsomeres); posterior margin of gonoplac with long row of dozen or so teeth (shorter row, with 8 teeth in Osaka).

\section{Description}

Vertex transverse. Frons with median and lateral carinae, lateral margins carinate. Clypeus with median carina. Pronotum longer than vertex in mid line. Mesonotum longer than wide, with three well visible carinae, carinae connected at base, lateral carinae reaching posterior margin of mesonotum, anterolateral carinae absent. Lateral angles placed anteriad of half of mesonotum length. Tegulae huge, carinate.

Tegmen flat, hyaline, with distinct venation. Tegmen with costal margin almost straight, apical and claval angles widely rounded, apical margin widely arcuate. Costal area slightly narrower than costal cell, with transverse veinlets, slightly widened in apical portion, without sclerotization in stigmal area, with apex at same level as claval apex. Costal cell without transverse veinlets. Basal cell longer than wide. Longitudinal veins weakly wavy. Stem $\mathrm{Sc}+\mathrm{RA}$ and stem RP leaving basal cell very close each other, without transverse veinlets to the level of $\mathrm{Sc}+\mathrm{RA}_{1}$ fork; first fork of RP apicad of level of nodal line. Stem M 
forked a little before stem $\mathrm{CuA}$ fork; branch $\mathrm{M}_{1+2}$ forked at level of nodal line, distinctly basad of stem $\mathrm{M}_{3+4}$ forking; branches $\mathrm{M}_{1}$ and $\mathrm{M}_{2}$ forked at level of nodal line; branch $\mathrm{M}_{3+4}$ forked before apical line. Branch $\mathrm{CuA}_{1}$ forked at level of apical line; $\mathrm{CuA}_{2}$ single. Claval veins Pcu and $A_{1}$ fused basad of half of clavus length. Two claval veinlet present: first between $\mathrm{CuP}$ and $\mathrm{Pcu}$, at base of clavus, second veinlet between $\mathrm{CuP}$ and $\mathrm{Pcu}+\mathrm{A}_{1}$ apicad of claval veins junction. First $r-m$ veinlet oblique, close to stem $M$ fork. First veinlet $m$-cua close to the basal cell. Nodal line of veinlets absent, subapical line of veinlets weakly developed, apical line of veinlets distinct. Apical cells longer than wide.

Hind wing hyaline, with very narrow and long precostal cell; stem $\mathrm{Sc}+\mathrm{R}$ forked at level of wing coupling lobe, branch $\mathrm{ScRA}_{1}$ reach the margin distinctly basad of wing apex, at level of $r-m$ veinlet, branch RA with two terminals reaching margin basad of wing apex; branch RP reaching the wing margin at wing apex, with three terminals. Stem M forked in apical portion of wing, reaching margin with three terminals; stem $\mathrm{CuA}$ forked distinctly basad of stem $\mathrm{Sc}+\mathrm{R}$ forking; distinctly basad of veinlets $r-m$ and $m$-cua, branch $\mathrm{CuA}_{1}$ forked basad of m-сиa veinlet, forked again before apex, reaching the margin with four terminals; branch $\mathrm{CuA}_{2}$ forked in apical portion reaching margin with three terminals. Transverse veinlets $r-m, m$-сиа and iсиа present; $r-m$ placed apicad of $m$-сиa veinlet, iсиa veinlet placed slightly basad of $m$-cua veinlet.

Femora of fore and midlegs slightly shorter than tibiae; tarsal claws and arolium bigger than tarsal claws and arolium of hind legs.

Hind tibia longer than hind femur, single lateral spine placed very distad from base; apical straight row of 7 teeth of same size; basitarsomere massive, as high as long, with 2+6 teeth formula; apical hind tarsomere distinctly longer than midtarsomere, about as long as cumulative length of basi- and midtarsomere.

Pregenital sternite with well-developed lateral lobes, posterior margin in median portion with rounded process; gonoplac laterally flattened, with posterior margin placed about 45 degree to longitudinal axis of body, with single row of well-developed teeth (13-15). Anal tube covering gonoplac, reaching its posterior margin; posterior margin of anal tube weakly concave.

\section{Yuripopoverus africanus sp. $\mathbf{n}$.}

(Figs 1-15)

2002 STROIŃSKI \& SZWEDO: 61, Osaka sp. 2.

\section{Diagnosis}

This is the only species in this genus. 

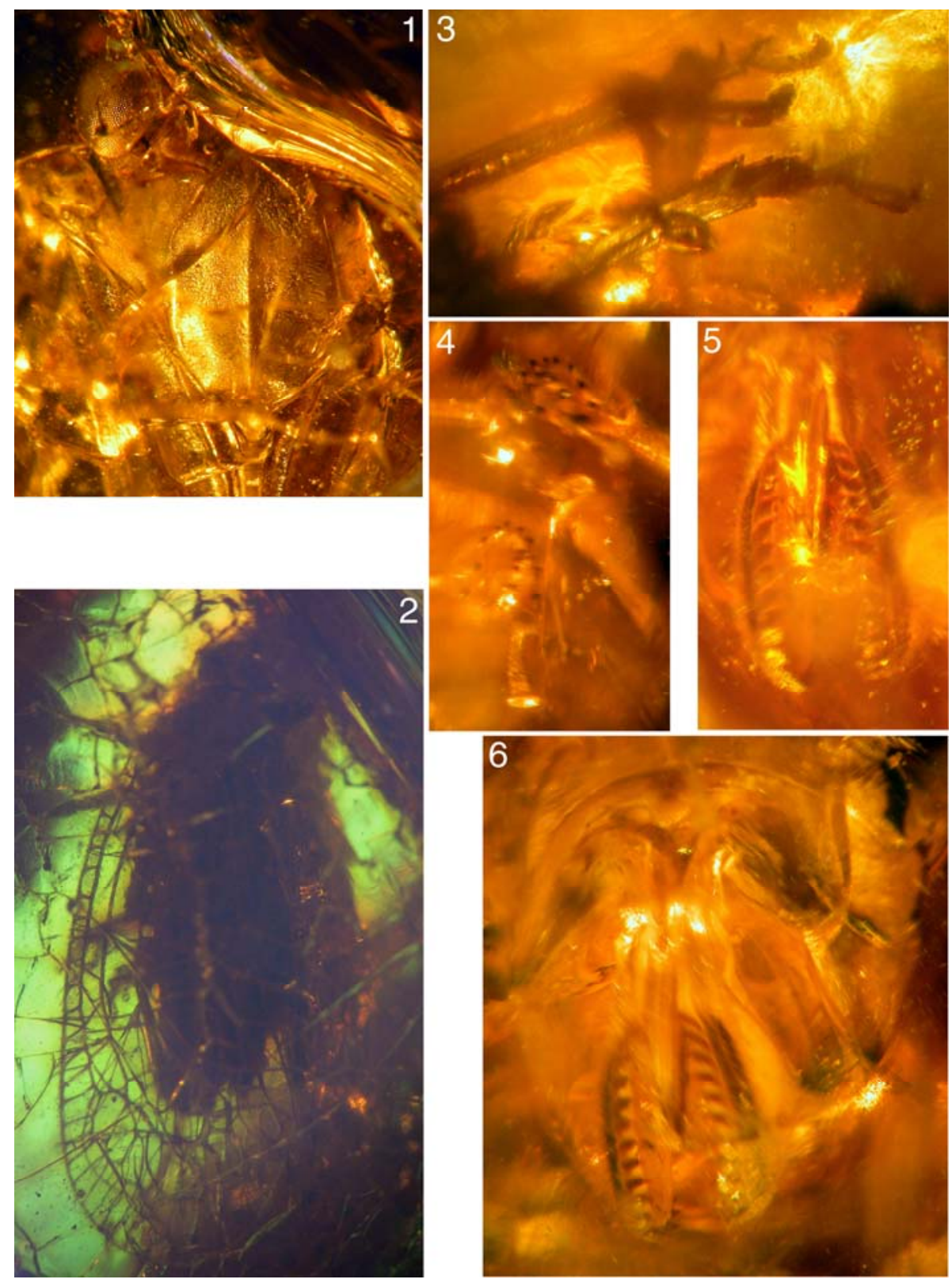

Figs 1-6. Yuripopoverus africanus gen. et sp. n.: 1 - anterior portion of body, 2 - general view in resin, 3 - hind tarsi, 4 - apical teeth of hind tibia and tarsi, 5 - apex of gonoplac, 6 - female genital structures in posteroventral view. 

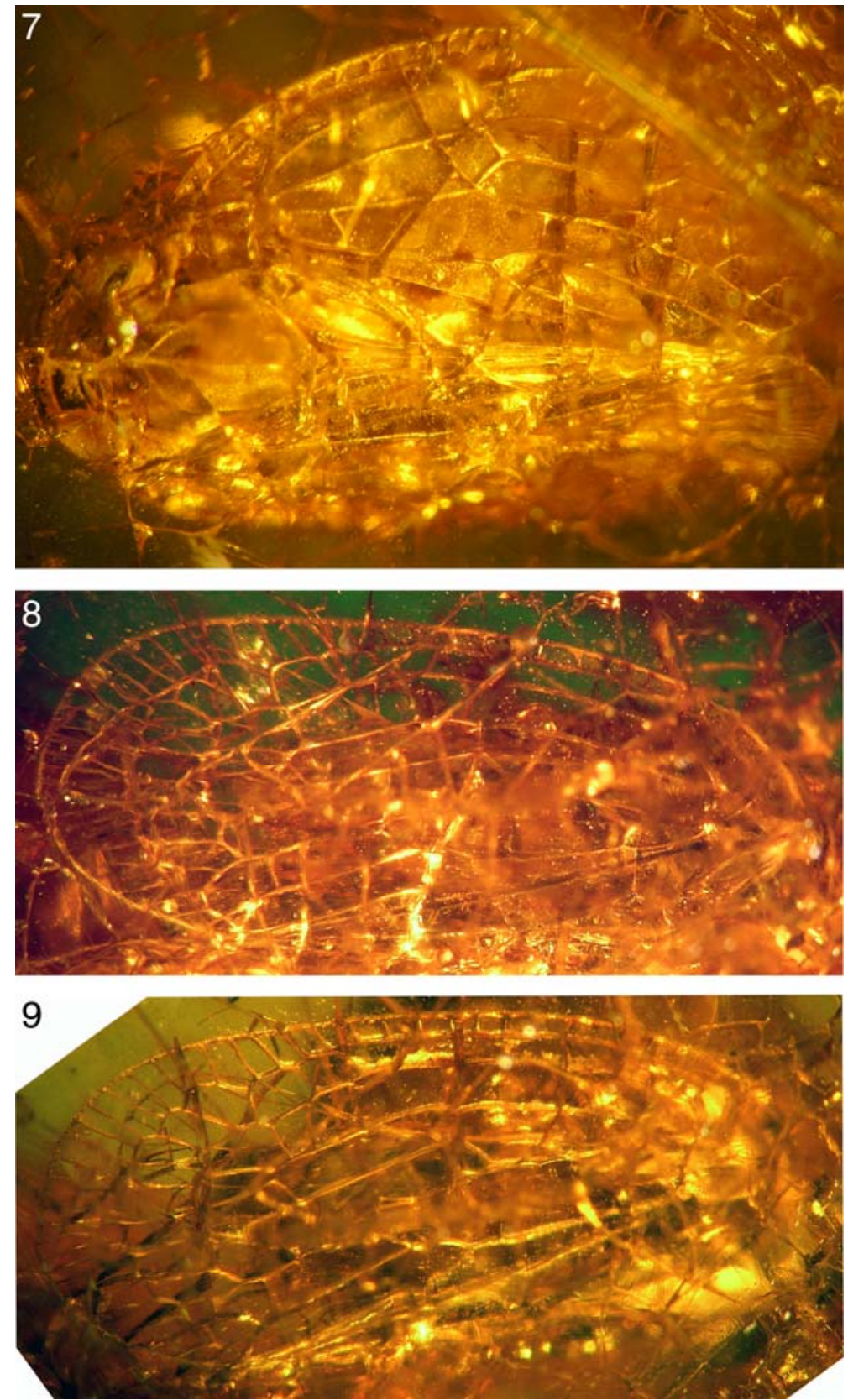

Figs 7-9. Yuripopoverus africanus gen. et sp. n.: 7 - anterior portion of body and right tegmen, 8 left tegmen, 9 - left tegmen. 


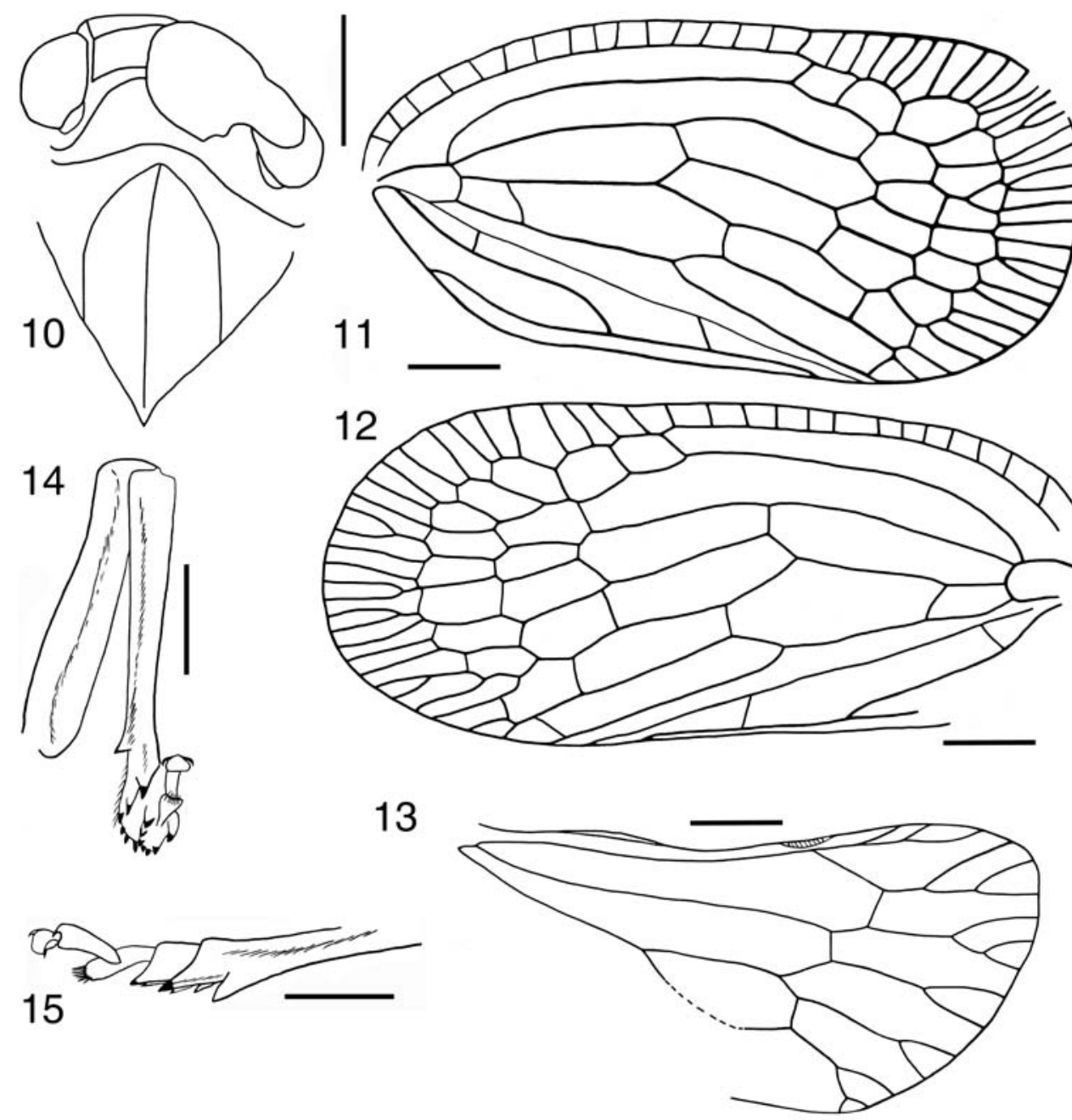

Figs. 10-15. Yuripopoverus africanus gen. et sp. n.: 10 - anterior portion of body, 11- right tegmen, 12 - left tegmen, 13 - left hind wing, 14 - left hind leg, 15 - right hind tarsus. Scale bars $1 \mathrm{~mm}$ for $10-13,0.5 \mathrm{~mm}$ for 14,15 .

\section{Description}

Total length $8 \mathrm{~mm}$. Length of tegmen about $7.8 \mathrm{~mm}$, width of tegmen about $3.3 \mathrm{~mm}$. Head with compound eyes $2.3 \mathrm{~mm}$ wide; pronotum about $1.8 \mathrm{~mm}$ wide, mesonotum about $2.06 \mathrm{~mm}$ long and $1.93 \mathrm{~mm}$ wide. Hind tibia $1.44 \mathrm{~mm}$ long, basitarsomere $0.32 \mathrm{~mm}$ long, mid tarsomere $0.28 \mathrm{~mm}$ long, apical tarsomere with tarsal claws about $0.37 \mathrm{~mm}$, without 
tarsal claws about $0.3 \mathrm{~mm}$; combined length of apical and mid tarsomere about $0.54 \mathrm{~mm}$. Vertex with anterior and posterior margins arcuate, parallel, lateral margins straight. Median portion of clypeus convex. Tegmen about 2.5 times as long as wide, with apex of clavus reaching $2 / 3$ of tegmen length. Stem $M$ of tegmen reaching apical margin with 9 (right tegmen ) to 12 (left tegmen) terminals.

Coloration (in resin). Abdomen, legs and gonoplac yellowish with dark brown smudge on posterior margin of gonoplac. Tegmina translucent, with veins patchily coloured with light and dark spots. Vertex in lateral portion with a few black spots, mesonotum with a few dark spots in posterior portion.

\section{Comment}

The measurements, drawings and photographs may be somewhat distorted because of the optical properties of the resin.

\section{Etymology}

The specific epithet refers to its geographical distribution.

\section{Type material}

Holotype, female; deposited in the Museum of Natural History, Vienna. Inclusion in subfossil animè resin ('East African copal'). The piece of resin is covered with cracks, and part of the upper portion of the head and pronotum of the inclusion is damaged. Labelled: [Spine. / Fulgoride! / Ostafr. Copal / Coll: Mayr]; [Naturhistorisches Museum in Wien / Akquisition: 1984/31/30-C / Homoptera - Fulgoroidea / Ost. afr. Copal / Kollektion A. Handlirsch / Geologisch-paläontologische Abteilung].

\section{DISCUSSION}

East African copal, also called Zanzibar copal, is a kind of fossil resin, which originates from a small area on the East African coast. It has been traded since Antiquity (LANGENHEIM 2003), and 'Kopalgruben' (copal mines) existed near Dar es Salaam (the coast of Tanzania) in the $19^{\text {th }}$ century (SCHLÜTER \& VON GNIELINSKI 1987). HOPE (1837) reserved the term 'copal' only for resins from the New World, applying the term 'animè' to the resins of the Old World. According to his explanations, the Portuguese first gave the name of Animè to the resin of Malabar, probably from observing insects embedded in its substance, calling it Animè, or 'animated', which is the significance of the Lusitanian word. HOPE (1837) also applied the term animè to the resin (with inclusions!) of the Hymenea tree from Madagascar. On the other hand, the East African and Madagascan subfossil resins (copals) are exuded by a tree of the same Hymenaea genus as the copals and ambers (Dominican and Mexican) from the New World. Be that as it may, we propose to follow HOPE's opinion, so as to separate the subfossil (subrecent) resins of the Americas from those known from Africa. 
East African animè is very rich in inclusions, although a few Fulgoromorpha have been mentioned. So far, inclusions from the following families have been identified: Derbidae, Issidae and Ricaniidae (STROIŃSKI \& SzWEDO 2002, STROIŃSKI 2007, 2010). East African animè is derived almost entirely from the trees of Hymenaea verrucosa GAERTNER, 1971 (Fabaceae), recently restricted (in natural localities) to East Africa and Zanzibar (PoINAR 1992, GeinAERT 2002, LANGENHEIM 2003). The problem of the age of animè from East Africa is still a matter of debate. Following their radiocarbon analysis, BURLEIGH \& WHALLEY (1983) gave no minimum age but described this resin as a very modern one. Moreover, SCHLÜTER \& VON GNIELINSKI (1987) claim that it stems from the Pleistocene and is no older than the Pliocene. KosmowsKa-CERANOwicz (2001) discussed the age of copals (young semifossilized resins), lending her support to their Pleistocene age. GEINAERT (2002) suggested that East African copal was about 100,000 years old. The ambiguous definitions of 'copals' and various opinions about the age of these resins were recently summarized by MATUSZEWSKA (2010). However, the only possible conclusion at the moment is that it is much younger than Baltic amber, with ages between several hundreds and many thousands of years (FEIST et al. 2007). It must be pointed out that most recent discussions and investigations relate to animè ('copal') from Madagascar (PENNEY et al. 2005, Feist et al. 2007, BosselaERs et al. 2010), not from Zanzibar or the East African coast.

The genus described above is the first one that has not yet been found among the representatives of recent Afrotropical Ricaniidae. HANDLIRSCH (1925) listed several recent genera of Fulgoroidea from 'Kopal', and these data were later repeated by SPAHR (1988), but without any additional comments on the origin of particular samples. The provenance of these inclusions is not clear, as these resins ('Kopals') originated from East and West Africa, India and Brazil (HANDLIRSCH 1925: 126), and their origin was not specified in the list of taxa. A number of arthropod inclusions described recently from Madagascan animè have also been placed in recent genera or even recent species (WUNDERLICH 2004, PENNEY et al. 2005, BosSELAERS et al. 2010, JUDSON 2010). It must be underlined that BURLEIGH \& WHALLEY (1983) estimated the age of some 'copals' they studied at about 50 years. Similar results were obtained for some samples of Madagascan animè (WUNDERLICH 2004), which can be explained by taxonomic studies. On the other hand, the age of East African animè is not precisely defined; this resin could be much older as it is flushed out from deep, underground layers (SCHLÜTER \& VON GNIELINSKI 1987). It seems very probable that recent representatives of the genus Yuripopoverus gen. n. could be found in the Afrotropical Region. This statement is supported by the findings of species of the genus Acroprivesa SCHMIDT, 1912 in East African animè and in recent fauna (STROIŃSKI 2010). The resiniferous tree Hymenaea verrucosa grows in one of the seven sub-Saharan sites of recognized plant diversity and endemism, which is probably also a glacial refugium 
(HAMilton 1982, LINDER 2001). The present distribution of the genus Acroprivesa suggests an East African origin and post-glacial expansion and evolution. Environmental data for extinct and recent species indicate that it is probably connected with trees and bushes of the family Fabaceae growing in the ecoregion of the Zambezian and Mopane Woodlands (STROIŃSKI 2010). It seems very probable that Yuripopoverus gen. n. also covers taxa related to this type of habitat, revealing similar host-plant relationships. In our opinion much more attention and comprehensive research focused on geology, chemistry and entomology are necessary with respect to the fossilized resins of the Afrotropical Region. Such research will contribute greatly not only to insect taxonomy, but also to the reconstruction of African vegetation, the history of African biota, the biogeography of this area, evolutionary and co-evolutionary studies, and also to habitat and environmental protection.

\section{REFERENCES}

Bosselaers J., Dierick M., Cnudde V., Masschaele B., Van Hoorebeke L., Jacobs P. 2010. Highresolution X-ray computed tomography of an extant new Donuea (Araneae: Liocranidae) species in Madagascan copal. Zootaxa 2427: 25-35.

BURLEigh R., WhALLEY P. 1983. On the relative geological ages of amber and copal. Journal of Natural History 17(6): 919-921.

Feist M., LAMPREChT I., MÜLleR F. 2007. Thermal investigations of amber and copal. Thermochimica Acta 458: 162-170. doi:10.1016/j.tca.2007.01.029

GeInAert E. 2002. L'Ambre. Miel de Fortune et Memoire de Vie. Les Editions du Piat, Monistrolsur-Loir, $176 \mathrm{pp}$.

HAMILTON A.C. 1982. Environmental history of East Africa: a study of the Quaternary. Academic Press, London, New York, 328 pp.

HANDlirsch A. 1925. Palaeontologie. [In:] SCHRÖDER C. (ed.). Handbuch der Entomologie. Gustav Fischer, Jena 3: 117-306.

Hope F.W. 1837. Observations on succinic insects. Part the second. Gums and resins. Transactions of the Royal Entomological Society of London 2: 46-57.

JudSON M.L.I. 2010. Redescription of Chelifer eucarpus DALMAN (Arachnida, Chelonethi, Withiidae) and first records of pseudoscorpions in copal from Madagascar and Colombia. Palaeodiversity 3: $33-42$.

KoSMOWSKA-CERANOwiCz B. 2001. Bursztyn i inne żywice kopalne świata. Kopale i żywice sztuczne - imitacje lub fałszerstwa bursztynu. Polski Jubiler 1(12): 24-27. [In Polish].

LANGENHEIM J.H. 2003. Plant resins: chemistry, evolution, ecology and ethnobotany. Timber Press, Portland, Cambridge, 586 pp.

LINDER H.P. 2001. Plant diversity and endemism in sub-Saharan tropical Africa. Journal of Biogeography 28: 169-182.

MATUSZEWSKA A. 2010. Bursztyn i inne żywice kopalne, subfossylne i współczesne. Uniwersytet Śląski. Oficyna Wydawnicza Wacław Walasek, Katowice, 234 pp. [In Polish].

Penney D., Ono H., Selden P.A. 2005. A new synonymy for the Madagascan copal spider fauna (Araneae, Selenopidae). Journal of Afrotropican Zoology 2: 41-44.

PoINAR G.O. Jr. 1992. Life in amber. Stanford University Press, Palo Alto, California, 350 pp.

SCHLÜTER T., VON GNIELINSKI F. 1987. The East African copal its geologic, stratigraphic, 
paleontologic significance and comparison with fossil resins of similar age. National Museums of Tanzania Occasional Paper 8: 32 pp.

SPAHR U. vON 1988. Ergänzungen und Berichtigungen zu R. Keilbachs Bibliographie und Liste der Bernsteinfossilien*) - Überordnung Hemipteroidea. Stuttgarter Beiträge zur Naturkunde, Serie B (Geologie und Paläontologie) 144: 1-60.

STROIŃSKI A. 2007. Pochazoides szwedoi n. sp. from the East African copal (Hemiptera: Fulgoromorpha: Ricaniidae). Genus 18(3): 345-349.

StRoIŃSKI A. 2010. Revision of the African genus Acroprivesa SchmidT, 1912 (Hemiptera, Fulgoromorpha, Ricaniidae). Deutsche Entomologische Zeitschrift 57(2): 259-270.

StroiŃSKi A., Szwedo J. 2002. An overview of Fulgoromorpha and Cicadomorpha in East African copal (Hemiptera). [In:] Holzinger W. (ed.). Zikaden - Leafhoppers, Planthoppers and Cicadas (Insecta: Hemiptera: Auchenorrhyncha), Denisia, 04, zugleich Kataloge des OÖ. Landesmuseums, Neue Folge Nr. 176: 57-66.

WUNDERLICH J. 2004. Subrecent spiders (Araneae) in copal from Madagascar, with descriptions of new species. Beiträge zur Araneologie 3B: 1830-1853.

Received: November 21, 2011

Accepted: November 30, 2011 